\title{
Examining Raw Material of Stone Tools. Siliceous Marl from the Eastern Part of the Polish Carpathians Re-interpreted
}

\author{
Andrzej Pelisiak $^{a}$
}

\begin{abstract}
Neolithic and Early Bronze Age communities which settled the eastern Carpathians Forelands and Carpathian Foothills used a variety of local and non-local siliceous raw materials. Silicites identified in archaeological material differ in quality and usefulness for making tools. Obsidian, Jurassic flint from the Cracow-Częstochowa Uplands, 'chocolate' flint, and Świeciechów (grey white-spotted) and Volhynian flints are the best quality. They were commonly used from the Early Neolithic onwards. On the other hand, some local raw materials were also in used. Among them the so-called Dynów marl or siliceous marls were suggested as the most popular. To correct the classification of raw material of these artefacts $\mathrm{HCl}$ (Hydrochloric acid) was used for testing both raw material samples and the artefacts of the so-called Dynów or siliceous marls. The results of the analysis shows that so-called Dynów or siliceous marl consists of several different raw material varieties. More than $50 \%$ of the analysed tools were of yellowish or grey-yellowish hornstones (cherts). Both siliceous marls and the chert came probably from different sources and each one has a different chemical composition and physical properties.
\end{abstract}

KEY-WORD: Siliceous marl, chert, Carpathians, Neolithic, Early Bronze Age

\section{INTRODUCTION}

The fertile soils of the loess upland belt of the eastern Polish Carpathian Forelands were of excellent value for early pastoral communities. This zone start to be densely settled from the very beginning of the Neolithic. From about 3800 BC, the lower parts of the Eastern Carpathian Foothills also entered into the Neolithic oecumene (Pelisiak 20I8b).

The Neolithic and Early Bronze Age communities that settled the eastern Carpathian Forelands and Carpathian Foothills used a variety of local and non-local siliceous raw materials. The silicites registered in the archaeological material differ in quality and usefulness for making tools. Obsidian, Jurassic flint from the CracowCzęstochowa Uplands, 'chocolate' flint, Świeciechów (grey white-spotted) and Vol-

\footnotetext{
a Institute of Archaeology, University of Rzeszów, Io Moniuszki str. 35-0I5 Rzeszów, Poland; e-mail: a.pelisiak@gmail.com
} 
I92 Pelisiak

hynian flints are of the best quality. They were commonly used from the Early Neolithic onwards. However, their frequency in the lithic assemblages of subsequent Neolithic and Early Bronze Age cultures is significantly different (Kozłowski 1970; Kaczanowska and Lech 1977; Kaczanowka 1985; Czopek and Kadrow 1988; Kadrow 1990, 1997; Zakościelna 1996; Kukułka 1998; Valde-Nowak 1999, 2000; Valde-Nowak and Gancarski 1999; Mitura 2004, 2006, 2007; Dębiec 2005; Szeliga 2009; Pelisiak and Rybicka 20I3; Dębiec et al., 20I4; Dobrzyński et al., 20I4; Pelisiak 20I7a, 20I7b).

On the other hand, some local raw materials were also in use. Among them the socalled Dynów marls or siliceous marls were frequently noted in the assemblages. The so-called Dynów marl was probably for a first time recognized in Neolithic material found near Wesoła village, Brzozów district, on the Dynów Foothills (Dagnan-Ginter and Parczewski 1976), and the sources of this raw material were suggested to be in the Baryczka River valley close to Nozdrzec, Hłudno, Wesoła and Barycz villages (Brzozów district; Parczewski 1986).

Numerous items made of so-called Dynów or siliceous marls were registered in the strong archaeological context (settlements, burials) of all Neolithic and Early Bronze Age cultures in SE Poland, e.g., from Linear Pottery culture sites in Zwięczyca, Site 3 (actually part of Rzeszów town; Dębiec et al., 20I4), Cieszacin, Site 4I, Jarosław district (Dębiec et al., 20I5), and Rzeszów, Site II7 (Czopek et al., 20I4); the Funnel Beaker culture site in Przybówka, Site I, Krosno district (Gancarski et al., 2008); Corded Ware culture sites in Szczytna, Site 6, Jarosław district (Pelisiak 2017a) and Średnia, Site 3, Przemyśl district (Jarosz 2002); Mierzanowice culture sites in Boratyn, Site I7, Jarosław district (Nowak 2016), Kańczuga, Site 5 KM, Przeworsk district (Koperski and Kostek 1997) and Jarosław, Site 158 (Pelisiak and Rybicka 2013), and Otomani-Füzesabony culture sites in Trzcinica, Site I, Jasło district (Gancarski and Valde-Nowak 1999) and Jasło, Site 29, (Gancarski and Valde-Nowak 1999). Also numerous blades, flakes, rectangular axes and waste from their preparation or repair, and bifacial axes have been discovered as single finds (Dagnan-Ginter and Parczewski 1976; Valde-Nowak 1988; Pelisiak 20I3, 20I7b). An exceptional site was discovered on the Cergowa (Mała Cergowa) Mountain near Dukla town, Krosno district. Exposures of lithic raw materials and the workshop remains found there shows the exploitation of these silicities at least in the Late Neolithic (Budziszewski and Skowronek 20oI).

\section{RE-INTERPRETATION OF RAW MATERIAL}

Hydrochloric acid $(\mathrm{HCl})$ was used for testing raw material samples and the artefacts. The first tests of raw material previously classified as siliceous marl were done by myself and Antonin Prichystal (Institute of Geological Sciences, Faculty of Science, Masaryk University) during the conference 'Flint in time and space - Time and space in flint. 
Characteristics and distribution of siliceous rocks in prehistory' held in the Institute of Archaeology and Ethnology Polish Academy of Sciences in Warsaw in May 2017. Surprisingly, the tested material did not positively react with $\mathrm{HCl}$. As a result, both the samples from the quarries and artefacts tested at the time, turned out not to be a siliceous marl but a yellowish chert (hornstone). The results of these tests were an inspiration for testing more raw material samples and artefacts previously described as made of siliceous marls.

Thirty-seven archaeological artefacts and samples of raw materials were examined: samples from the quarries in Bircza-Krępak, Malawa and Leszczawa (Przemyśl Foothills), and Ulanica (Dynów Foothills) and the artefacts from Linear Pottery, Funnel Beaker, Corded Ware and Mierzanowice cultures sites as well as single finds were subjected to analysis (Fig. I).

The analysis has only recently begun but the results are surprising. They show that more than 50\% of the analyzed artefacts previously described as made of Dynów/siliceous marl were in fact of yellowish or grey-yellowish hornstone (cherts). Moreover, the so-called Dynów or siliceous marl consists of several different raw material varieties. Both siliceous marls and the cherts may come from different sources and each one has different chemical composition and physical properties.

Within the set of analyzed artefacts, two main groups of raw material ware identified: cherts (hornstones) and siliceous marls.

The cherts (hornstones) differs in respect of colour and usefulness for tool making. If taken out of their primary sources, the basic mass of these cherts is yellowish, greyyellowish, greenish-yellow or light brown of uniform tint, and flaked surfaces have a mild waxy shine. It is dull or almost dull, sometimes little shiny, opaque or slightly translucent. Cherts of all these variety are compact with a 'greasy' surface. The fracture is platy-flaky or conchoidal. Raw material obtained from the primary autochthonous deposits is fractures well. In the outcrops cherts of different colours occur in several beds, several or tens of centimeter apart. The cherts are more or less clearly separated from the surrounding rock. The thickness of layers and oblong lenses and slabs oscillate from 2 to $15 \mathrm{~cm}$. The sinuous layers are nearly horizontal or vertical depending on the tectonic activity in this area. This made the cherts relatively easy to reach and extract. The slabs of raw material were suitable for breaking into tabular forms easy to shape axes. Cherts of very similar or almost identical colour and physical features appear at many Carpathian outcrops (Fig. 2).

There seem to be two varieties of siliceous marl used to make the analysed stone artefacts:

I. Highly weathered light grey or light-grey-yellowish siliceous marl, the colour can be lighter when dry and darker when wet. It is pumice-like, very porous and has a texture with cavities. The raw material registered in stone artefacts is two-three times lighter than 'fresh' siliceous marl from primary deposits, because 'the calcium 
$194 \mid$ Pelisiak

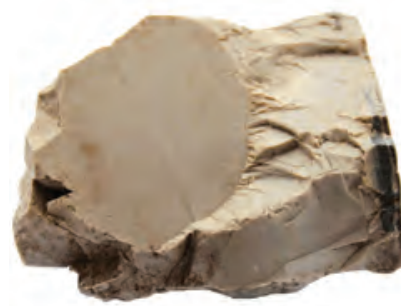

A

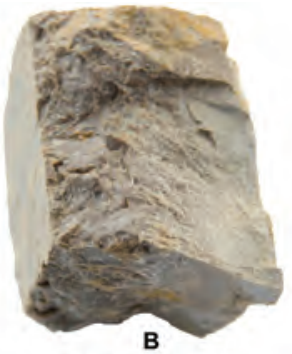

B

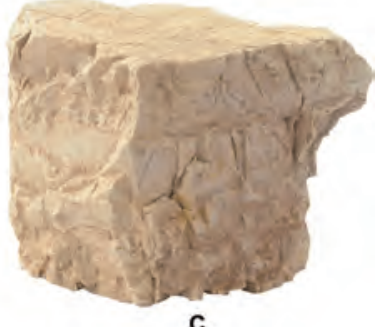

C

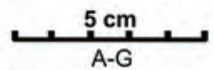

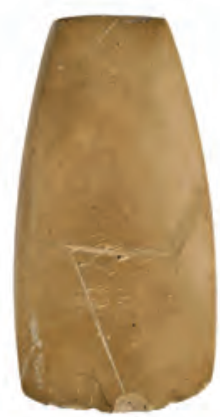

D

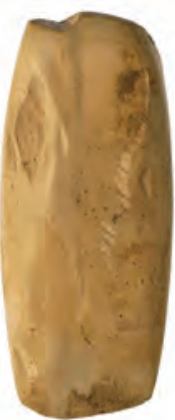

E

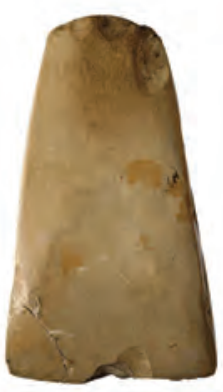

$\mathbf{F}$

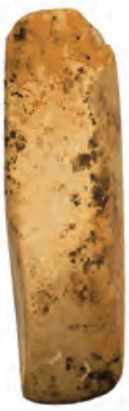

G

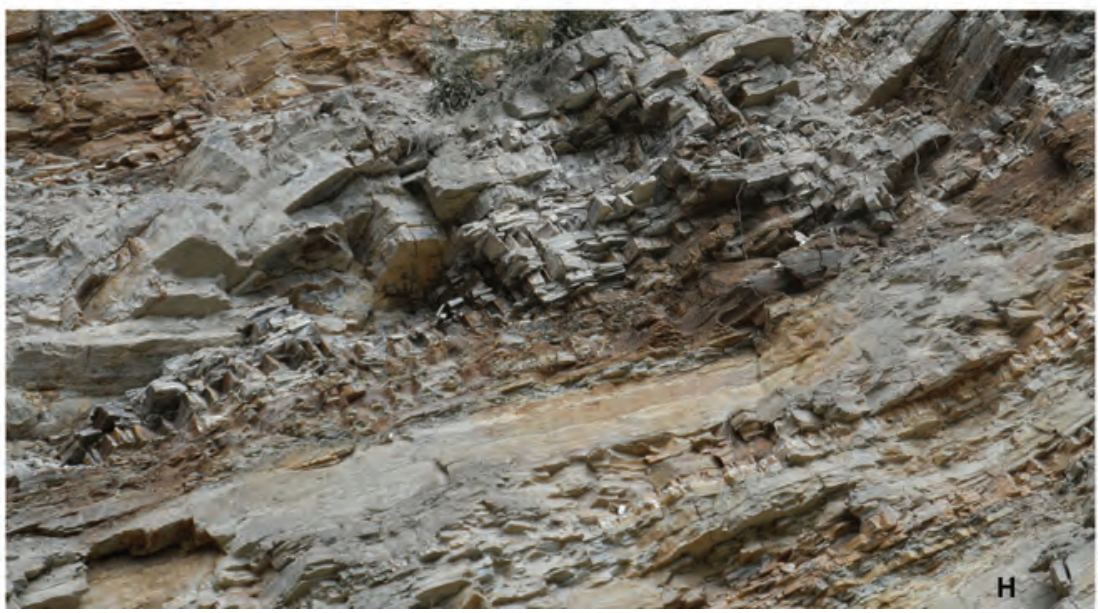

Fig. 1. Raw material samples (A-C), axes (D-G) and outcrops at Hermanowa, Rzeszów distr.

( $\mathrm{H}$ - layers of siliceous marls and cherts). D- $\mathrm{G}$ - single finds of artefacts made of chert macroscopically similar to siliceous marl, D-F - single finds, G - Linear Pottery culture sites at Rzeszów (Site 117); A - Krępak, Bircza commune, Przemyśl distr.; B - Malawa, Bircza commune, Przemyśl distr.; C - Leszczawa, Bircza commune, Przemyśl distr.; D - Morochów, Zagórz commune, Sanok distr.; E - Pakoszówka, Sanok commune, Sanok distr; F - Pielna, Zarszyn commune, Sanok distr; G - Rzeszów, Site 117, Rzeszów distr. Photo: A. Pelisiak and P. Kotowicz. 
dominant in non-weathered rock, appears to be easy removable by chemical weathering' (Budziszewski and Skowronek 200I: 157). Some artefacts can even float on the surface of water. The artefacts are very soft and they are easy to break and crumble. Because of the strong physical transformations of the raw material the axes and other tools are unusable in their present form. The artefacts differ in the degree of physical

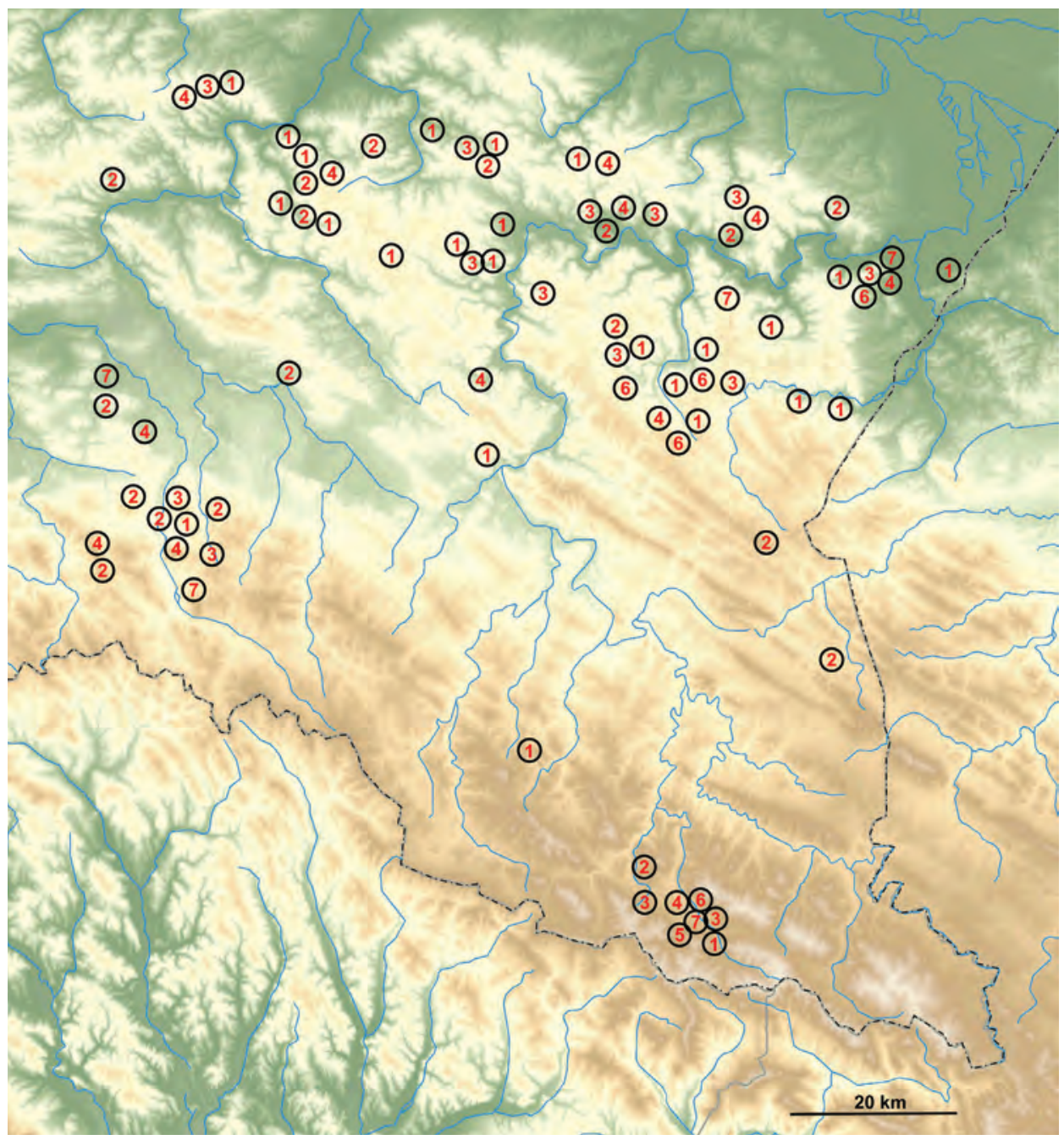

Fig. 2. Outcrops of siliceous raw material in the eastern part of the Polish Carpathians. 1 - siliceous marls including so called Dynów marl; 2 - black menilite hornstones; 3 - brown menilite hornstones; 4 - other hornstones (striped, yellowish); 5 - siliceous sandstones; 6 - so-called Bircza flint and similar rocks; 7 - flysch radiolarites. After: Pelisiak 2018b: Fig. 8,2 modified. Computer graphics: A. Pelisiak 
I96 | Pelisiak

transformation of the raw material and degree of weathering of the siliceous marl. This may depend on the soil acidity and the length of time the artefact was in such an acid environment. It should also be emphasized that the high degree of weathering and transformation of the artefacts make the identification of the primary physical characteristics of the raw material used for the production of these artefacts extremely difficult. Probably the physical features were similar to those of the material included in the second group described below.

2. In a fresh condition in the primary autochthonous and secondary autochthonous deposits this material is predominantly yellowish, grey-yellowish, greenish-yellow or light brown. This variety of siliceous marl is slightly translucent or non-translucent. In a fresh condition it fractures well and the flaked surfaces have a greasy or dull-greasy lustre. The quality is good for knapping. In the outcrops, siliceous marls occur in several levels up to $15 \mathrm{~cm}$ thick, several or tens of centimetres apart. The raw material is not clearly separated from the bedrock. The sinuous layers are in nearly horizontal and vertical position depending on tectonic activity on this area. This position meant that the siliceous marls were relatively easy to reach and extract. The slabs of siliceous marls are suitable for breaking into tabular forms easy to shape into axes. It should be noted that raw materials of the same type from many Carpathian outcrops could be very similar or almost identical.

The general characteristics presented above shows that in many cases, based only on an examination of the raw material of stone artefacts by the naked eye, it is difficult or impossible to properly recognize the raw material and distinguish the yellow or grey-yellow chert (hornstone) from siliceous marl.

\section{DISCUSSION}

Both cherts and siliceous marls were used for the production of axes and flake tools. Due to their physical features, they were of limited usefulness for preparation of blade cores and blade production. Consequently, blades and blade tools made of these raw materials are very rare in lithic assemblages. The axes constitute the most frequent and spectacular group of tools dated to the Neolithic and Early Bronze Age. It should be also emphasized that in the area of the eastern part of the Polish Carpathian Foothills, the siliceous marls and cherts are the only local lithic raw materials useful for production of axes using chipping methods.

Both siliceous marls, and yellowish and grey-yellowish cherts are present in many locations on the Dynów, Strzyzów and Przemyśl foothills as well as in the other parts of the eastern Polish Carpathians (e.g., Wdowiarz 1949; Gucik 196I; Kotlarczyk et al., 1977; Lesczyński et al., 1995; Rajchel and Myszkowska 1998; Leszczyński 2003, 2004; Garecka 2008; Górniak 20II). The sources and use of these raw materials have also been discussed in the context of general prehistoric issues (e.g., Dagnan-Ginter and Parczewski 1976; Parczewski 1986; Valde-Nowak 1995a, 1995b, 2013; Budziszewski and Skowronek 200I; 
Pelisiak 20I6a, 20I6b, 20I8a). Moreover, systematic field survey for lithic raw material resources in the eastern part of Polish Carpathians have provided new information on the availability of cherts and siliceous marls at many localities in the region (Fig. 2; Pelisiak 2016a, 2018a).

According to the classification of Zsolt Mester (Mester 2013: I2) siliceous marls and cherts in the Eastern Polish Carpathians appear in primary autochthonous, secondary autochthonous and more rarely in sub-autochthonous or residual sources. Exposures on the steep slopes of the hills and dissected river valleys allow easy access to the best quality raw material in the primary autochthonous sources. Raw material from secondary autochthonous sources in the river beds was also available but it was of worse quality than material from the exposures.

The cherts and siliceous marls were rocks with properties that allowed effective production of axes. Large number of rectangular and bifacial axes made of siliceous marls and cherts found in SE Poland suggests a relatively large production of these tools. Blocks of chert or siliceous marls extracted even from primary autochthonous sources contain mostly cracked or crumbling pieces of raw material. Only a relatively small number of block or slabs were useful for tool production. This may suggest a large scale of extraction of cherts and siliceous marls, which took place at selected locations, intended to obtain enough good quality raw material for production of these tools.

The above suggestions lead to the hypothesis that raw material could have been obtained from primary sources using a mining method. However, in the area of the eastern part of Polish Carpathians no mine-site for siliceous marls or cherts have been found yet. On the other hand, the numerous outcrops of cherts and siliceous marls registered in the area of the Eastern Carpathian Foothills are located at a relatively small distance from the Early Neolithic settlements, from Funnel Beaker and Corded Ware culture as well as Early Bronze Age Mierzanowice culture sites (Fig. 3). This can suggests that cherts and siliceous marls were exploited mainly for local use or at most for regional needs.

With no doubt, the extraction methods of cherts and siliceous marls were determined by the geological conditions. The raw material could been extracted from open-air pits or quarrying niches cut into the walls of river valleys and hillsides where cherts or siliceous marls were to be found where they were exposed by the cuttings of the riverbed into the hill sides. Dozens of such a locations are known from the eastern part of Polish Carpathians, and at least some of them may have been potential areas of useful raw material acquisition.

However, even if such methods of raw material extraction can be presumed, the low archaeological visibility of traces of such activities and prehistoric digging activities in general should be emphasized. Thus, the traces left by the raw material exploitation could be difficult to observe. Furthermore, at least some of such structures will have been exposed to damage as a result of landslides and soil movement down steep slopes and may have been completely destroyed. 
$198 \mid$ Pelisiak

\section{CONCLUSIONS}

The correct identification of raw material type is of primary importance in the studies on economy and procurement strategies, contacts and interactions between Neolithic as well as Early Bronze Age communities. Extraction of raw material, chert and siliceous marl processing and distribution of tools and blanks reflects many elements of social organization and behaviour of prehistoric communities. Communication networks can also be reconstructed from the raw material composition of archaeological assemblages.
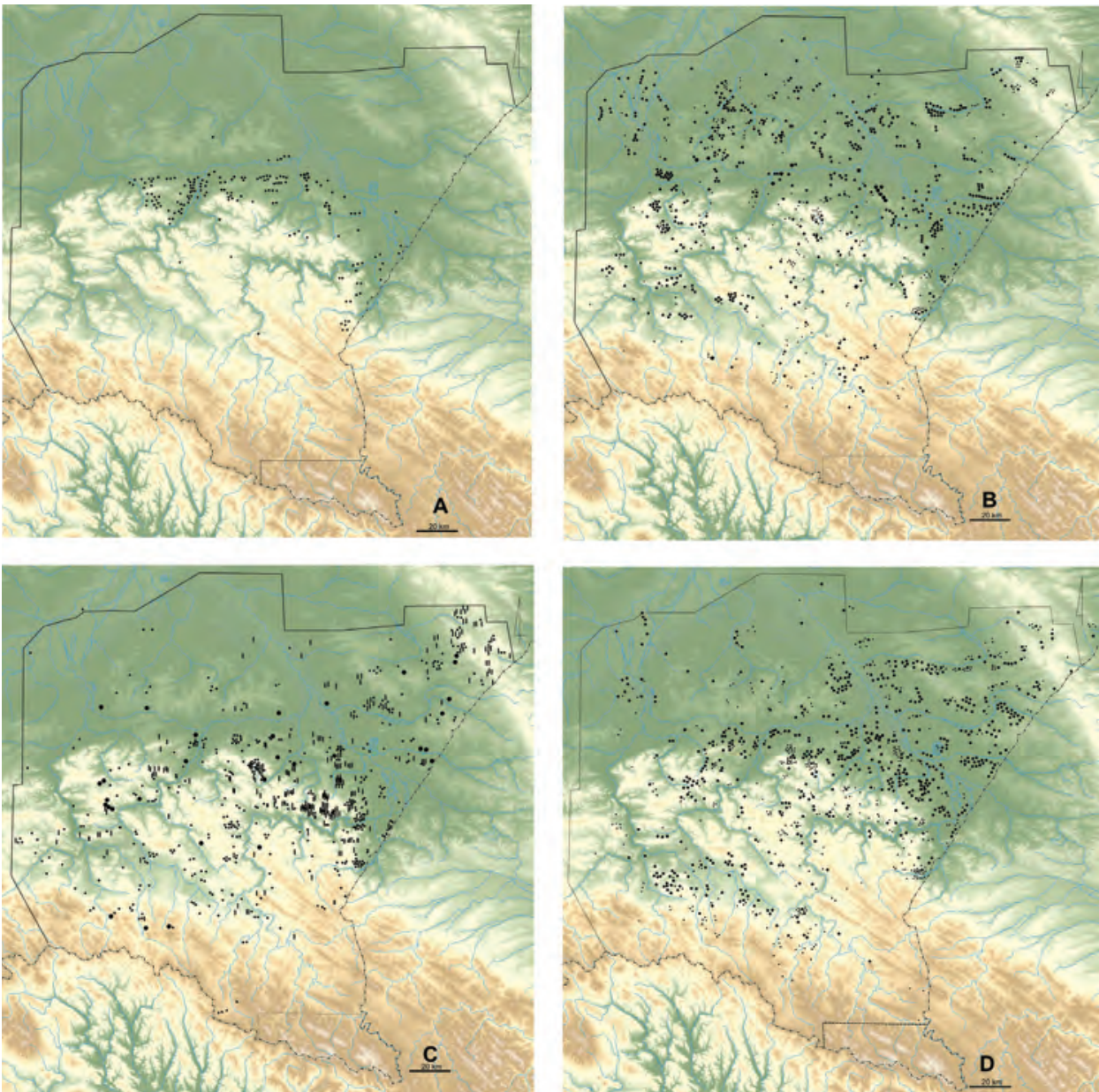

Fig. 3. Eastern part of the Polish Carpathians and Carpathian Forelands. Distribution of sites: A - Linear pottery culture; B - Funnel Beaker culture; C - Corded Ware culture; D - Mierzanowice culture. After: Pelisiak 2018b: Fig. 7.1; 7.6; 7.7; 7.8. 
Siliceous marls and cherts are the only raw materials suitable for manufacture of chipped and polished tools that come from the area of the Eastern Polish Carpathians. There are various potentially significant sources of siliceous marls and cherts suitable for manufacturing of chipped and polished tools. For prehistoric research the identification of primary sources of each type of raw material is very important, but precise identification of the provenience of raw material of the artefacts is a difficult task. Surprisingly, the opinion written by Paweł Valde-Nowak in 1995 referring to the identification of the cherts and siliceous marls in the archaeological material: 'the petrographic identification, the location of its deposits and, what is interesting, the correctness of the name of siliceous marl from the vicinity of Dynów, are still posing some difficulties' (Valde-Nowak 1995b: II6) is still current. For this reasons above, the results of raw material testing suggests: (I) the necessity for the re-analysis of large part of known artefacts previously interpreted as made of so-called Dynów or siliceous marl to correct their raw material classification, (2) the need for a comprehensive characterisation of these raw materials and their sources.

\section{REFERENCES}

Budziszewski, J. and Skowronek, M. 20or. Results of the Preliminary Archaeologicacl Research in the Mount Cergowa Massif, the Lower Beskid Mountains. In J. Machnik (ed.), Archaeology and Natural Background of the Lower Beskid Mountains, Carpathians, I45-I64. Kraków.

Czopek, S. and Kadrow, S. I988. Osada kultury pucharów lejkowatych w Białobrzegach, stan. 5, woj. Rzeszów. Sprawozdania Archeologiczne 39: 73-88.

Czopek, S., Niemasik, D., Pasterkiewicz, W. and Pelisiak, A. 20I4. Rzeszów, stanowisko II7-osada wielokulturowa. Rzeszów, Muzeum Okręgowe w Rzeszowie.

Dagnan-Ginter, A. and Parczewski, M. 1976. Dwie kolekcje archeologiczne z Pogórza Dynowskiego. Materiaty Archeologiczne I6: 5-28.

Dębiec, M. 2005. Materiały z badań ratowniczych na wielokulturowym stanowisku 3I w Rzeszowie. Materiaty i Sprawozdania Rzeszowskiego Ośrodka Archeologicznego 26: 25-63.

Dębiec, M., Dębiec, M. and Pelisiak, A. 2015. Cieszacin Wielki, stan. 4I, Pawtosiów, stan. 55 i Jankowice, stan. 9. Kompleks osad z epoki neolitu i wczesnej epoki brązu. Rzeszów, Fundacja Rzeszowskiego Ośrodka Archeologicznego.

Dębiec, M., Pelisiak, A., Becker, V., Dębiec, M., Makowicz-Poliszot, D., Saile, T., Sebők, K., Posselt, M. and Szczepanek, A. 2014 Zwięczyca 3. Eine bandkeramische Siedlung am Wistok. Rzeszów.

Dobrzyński, M., Parczewski, M., Piątkowska, K. and Rybicka, M. 20I4. Zabytki kultury pucharów lejkowatych w miejscowości Jasienica Sufczyńska, stan. 5 na Pogórzu Przemyskim. Materiaty i Sprawozdania Rzeszowskiego Ośrodka Archeologicznego 35: 249-258.

Gancarski, J. and Valde-Nowak, P. 1999. Bronzezeitliche Spaltindustrie der Pleszów- und der OtomaniFüzesabony-Kultur aus den Siedlung Trzcinica und Jasło. Ein Überblick. In J. Gancarski (ed.), Kultura Otomani-Füzesabony - rozwój, chronologia, gospodarka, I8I-200. Rzeszów, Muzeum Podkarpackie.

Gancarski J., Pasterkiewicz, W. and Pelisiak, A. 2008. Osada kultury pucharów lejkowatych w Przybówce, gm. Wojaszówka, stanowisko I. In J. Machnik (ed.), Archeologia i środowisko naturalne Beskidu Niskiego w Karpatach. Part II, Krimská Brázda, 347-378. Kraków, Prace Komisji Prehistorii Karpat 4. 
$200 \mid$ Pelisiak

Garecka, M. 2008. Granica Oligocen/Miocen w polskich Karpatach Zewnętrznych na podstawie nanoplanktonu wapiennego. Biuletyn Państwowego Instytutu Geologicznego 432: I-54.

Górniak, K. 20II. Origin of marls from the Polish Outer Carpathians; lithological and sedimentological aspects. Mineralogia 42(4): 163-297.

Gucik, S. 196I. Poziom wapieni detrytycznych z Birczy w Karpatach przemyskich i jego znaczenie dla stratygrafii górnej kredy i paleocenu w rejonie skibowym. Geological Quarterly 5: 669-685.

Jarosz, P. 2002. Kurhan kultury ceramiki sznurowej w Średniej, st.3/2, pow. Przemyśl. Wyniki badań wykopaliskowych przeprowadzonych w 200I r. Rocznik Przemyski 38(2): 3-2I.

Kaczanowska, M. 1985. Rohstoffe, Technik un Typologie der neolithischen Reuersteinindustrien im Nordteil des Flussgebietes der Mitteldonau. Warszawa, Państwowe Wydawnictwo Naukowe.

Kaczanowska, M. and Lech, J. 1977. The flint industry of Danubian communities north of the Carpathians. Acta Archaeologica Carpathica I7: 5-28.

Kadrow, S. 1990. The Rzeszów Settlement Microregion in Neolithic. Acta Archaeologica Carpathica 29: 33-70.

Kadrow, S. 1997. Osada kultury ceramiki wstęgowej rytej na stanowisku 3 w Rzeszowie-Staromieściu. Materiaty i Sprawozdania Rzeszowskiego Ośrodka Archeologicznego 18: 5-27.

Kotlarczyk, J., Mitura, F. and Rajchel, J. 1977. Inoceramus Salisburgensis z warstw inoceramowych w rejonie Rybotycz. Rocznik Polskiego Towarzystwa Geologicznego 47(3): 37I-38I.

Koperski, A. and Kostek, A. 1997. Zespół zabytków kultury mierzanowickiej na st. 5 w Kańczudze, woj. przemyskie. Rocznik Przemyski 34(3): 37-42.

Kozłowski, J. K. 1970. Z badań nad wytwórczością krzemieniarską w kulturze ceramiki wstęgowej rytej. In J. K. Kozłowski (ed.), Z badań nad kulturą ceramiki wstęowej rytej, 73-94. Kraków, Polskie Towarzystwo Archeologiczne.

Kukułka, A. 1998. Drugi sezon badań wykopaliskowych na osadzie wczesnoneolitycznej w Gwóźdźcu, stan. 2, gm. Zakliczyn. Materiaty i Sprawozdania Rzeszowskiego Ośrodka Archeologicznego 19: 175-199.

Leszczyński, S. 2003. Bioturbation structures in the Holovnia siliceous marls (Turonian-Lower Santonian) in Rybotycze (Polish Carpathians). Annales Societatis Geologirum Poloniae 73: I03-I22.

Leszczyński, S. 2004. Bioturbation structures of the Kropivnik Fucoid Marls (Campanian-lower Maastrichtian) of the Huwniki-Rybotycze area (Polish Carpathians). Geological Quarterly 48(I): 35-60.

Leszczyński, S., Malik, K. and Kędzierski, M. 1995. Margle krzemionkowe i fukoidowe w rejonie Rybitycz: nowe dane litofacjalne i stratygraficzne (Płaszczowina Skolska, kreda, Karpaty). Annales Societatis Geologirum Poloniae 65: 43-62.

Mester, Z. 20I3. The lithic raw material sources and interregional human contacts in the Northern Carpathian regions: aims and methodology. In Z. Mester (ed.), The lithic raw material sources and interregional human contacts in the Northern Carpathian regions, 9-2I. Kraków-Budapest.

Mitura, P. 2004. Materiały kultury malickiej i grupy tarnobrzeskiej ze stanowiska 54 w Rzeszowie. Materiaty i Sprawozdania Rzeszowskiego Ośrodka Archeologicznego 25: 5-90.

Mitura, P. 2006. Materiały kultury ceramiki wstęgowej rytej i kultury pucharów lejkowatych ze stanowiska 55 w Rzeszowie. Materiaty i Sprawozdania Rzeszowskiego Ośrodka Archeologicznego 27: 65-88.

Mitura, P. 2007. Workshop of flint processing and reparation of rectangular axes on site 34 in Niedźwiada, Ropczyce commune, podkarpackie voivodship. Sprawozdania Archeologiczne 59: 305-324.

Nowak, A. 20I6. Zabytki krzemienne i kamienne. In M. Glinianowicz, S. Kadrow, P. N. Kotowicz, A. Nowak, and W. Poradyło (eds), Boratyn, pow. jarostawski, stan. I7. Materiaty z osad kultury mierzanowickiej i grupy tarnobrzeskiej oraz z cmentarzyska wczesnośredniowiecznego, 5I-54. Rzeszów.

Parczewski, M. 1986. Pogórze Dynowskie w zaraniu dziejów. Brzozów, Muzeum Regionalne PTTK w Brzozowie.

Pelisiak, A. 20I3. Pojedyncze przedmioty kamienne a strefy aktywności osadniczej i gospodarczej w neolicie we wschodniej części Karpat Polskich. Materiaty i Sprawozdania Rzeszowskiego Ośrodka Archeologicznego 34: 19-33. 
\begin{tabular}{l|l} 
Examining Raw Material of Stone Tools & $20 \mathrm{I}$
\end{tabular}

Pelisiak, A. 20I6a. Siliceous raw material from Bieszczady Mountains. Sources and use. Archaeologia Polona 54: 7-16.

Pelisiak, A. 20I6b. W związku z okolicznością szczególną, o karpackich surowcach krzemionkowych uwag kilka. In B. Chudzińska, M. Wojenka, and M. Wołoszyn (eds), Tworzenie się stowiańskiej Europy w ujęciu źródtoznawczym, 739-745. Kraków-Rzeszów.

Pelisiak, A. 20I7a. Analiza zabytków krzemiennych z grobów kultury ceramiki sznurowej i domniemanych grobów kultury mierzanowickiej w Szczytnej, pow. Jarosław. In P. Jarosz and J. Machnik (eds), Nekropolie ludności kultury ceramiki sznurowej z III tysiąclecia przed Chr. w Szczytnej na Wysoczyźnie Kańczuckiej, 137-158. Rzeszów.

Pelisiak, A. $2017 \mathrm{~b}$. Materiały krzemieniarskie odkryte w trakcie badań powierzchniowych realizowanych $\mathrm{w}$ promieniu Io $\mathrm{km}$ od stanowiska $7 \mathrm{w}$ Skołoszowie, pow. jarosławski, woj. podkarpackie. In M. Rybicka (ed.), Wielokulturowe stanowisko w Skotoszowie, stanowisko 7, pow. jarostawski, w kontekście osadnictwa z neolitu i wczesnej epoki brązu we wschodniej części Podgórza Rzeszowskiego, 35-58. Rzeszów.

Pelisiak, A. 2018a. Siliceous Raw Materials from the Eastern Part of the Polish Carpathians and Their Use in Stone and Bronze Ages. In D.H. Werra and M. Woźny (eds), Between History and Archaeology. Papers in honour of Jacek Lech, 69-77. Oxford, Archaeopress.

Pelisiak, A. 20I8b. Centrum i peryferia osadnictwa w neolicie i wczesnej epoce brazu na wschodnim Podkarpaciu i we wschodniej części polskich Karpat. Rzeszów, Uniwersyet Rzeszowski.

Pelisiak, A. and Rybicka, M. 20I3. Stanowisko I58 w Jarostawiu, woj. podkarpackie. Część I. Kultura malicka i kultura mierzanowicka. Rzeszów, Via Archaeologica Ressoviensia 3.

Rajchel, J. and Myszkowska, J. 1998. Litologia wapieni z warstwy wapienia litotaminowego z Birczy (wt) - jednostka skolska, zewnętrzne Karpaty fliszowe. Przegląd Geograficzny 46: I247-I253.

Szeliga, M. 2009. Znaczenie obsydianu karpackiego w gospodarce surowcowej najstarszych społeczności rolniczych na ziemiach polskich. In J. Gancarski (ed.), Surowce naturalne w Karpatach oraz ich wykorzystanie w pradziejach i wczesnym średniowieczu, 287-324. Krosno, Muzeum Podkarpackie w Krośnie.

Valde-Nowak, P. 1988. Etapy $i$ strefy zasiedlenia Karpat polskich $w$ neolicie $i$ na początku epoki brazu. Wrocław.

Valde-Nowak, P. 1995a. Stone sources from the North-Carpathian province in the Stone and Early Bronze Ages. Archaeologia Polona 33: III-II8.

Valde-Nowak, P. 1995b. North-Carpathians province if lithic raw materials in Stone and Bronze Age. Archaeologia Polona 33: III-II8.

Valde-Nowak, P. 1999. Zabytki krzemieniarskie ze stanowiska 5 w Sieteszy, gm. Kańczuga, woj. podkarpackie. Rocznik Przemyski 35(2): 59-66.

Valde-Nowak, P. 2000. Zabytki kamienne ze stanowiska 5 w Sieteszy, pow. Przeworsk. Badania w I999 roku. Rocznik Przemyski 36(I): 33-36.

Valde-Nowak P. 20I3. The north-Carpathians province of silica rocks during Stone Age. In Z. Mester (ed.), The lithic raw material sources and interregional human contacts in the northern Carpathian regions, 87-99. Kraków-Budapest.

Valde-Nowak, P. and Gancarski, J. 1999. Bronzezeitliche Spaltindustrie der Pleszów und der OtomaniFüzesabony-Kultur aus den Siedlung Trzcinica und Jasło. Ein Überblick. In J. Gancarski (ed.), Kultura Otomani-Füzesabony - rozwój, chronologia, gospodarka, I8I-200. Krosno, Muzeum Podkarpackie w Krośnie.

Wdowiarz, S. 1949. Budowa Geologiczna Karpat Brzeżnych na potudniowy-wschód od Rzeszowa. Warszawa, Państwowa Stużba Geologiczna, Państwowy Instytut Geologiczny II.

Zakościelna, A. 1996. Krzemieniarstwo kultury wotyńsko-lubelskiej ceramiki malowanej. Lublin, Wydawnictwo Uniwersytetu Marii Curie-Skłodowskiej. 
